\title{
Effects of parity and body condition at parturition on endocrine and reproductive parameters of the cow
}

\author{
A Meikle ${ }^{1}$, M Kulcsar ${ }^{3}$, Y Chilliard ${ }^{4}$, H Febel $^{5}$, C Delavaud $^{4}$, D Cavestany ${ }^{1}$ and P Chilibroste ${ }^{2}$ \\ ${ }^{1}$ Faculty of Veterinary Medicine and ${ }^{2}$ Agronomy Sciences, University of Uruguay, Montevideo and Paysandú, \\ Uruguay, ${ }^{3}$ Szent Isvan University, Faculty of Veterinary Science, Budapest, Hungary, ${ }^{4}$ Unité de Recherche sur les \\ Herbivores, INRA-Theix, Saint-Genés-Champanelle, France and ${ }^{5}$ Research Institute for Animal Husbandry and \\ Nutrition, Herceghalom, Hungary \\ Correspondence should be addressed to A Meikle, Department of Cellular and Molecular Biology, Faculty of Veterinary \\ Medicine, University of Uruguay, Lasplaces 1550, Montevideo 11600, Uruguay; Email: anamei@adinet.com.uy
}

\begin{abstract}
The effect of parity (multiparous vs primiparous) and body condition score (BCS; $<3.0$ or $\geq 3.0$, lean vs fat) at parturition on metabolic and endocrine profiles from 1 month before to 2 months after parturition were studied in 42 Holstein cows grazing on improved pastures. BCS and milk production were determined every 2 weeks. Non-esterified fatty acids (NEFA), $\beta$-hydroxybutyrate (BHB), insulin, IGF-I, leptin, thyroxine (T4) and 3,3',5-tri-iodothyroinine (T3) were determined in plasma every 10 days. Progesterone was determined three times per week after parturition. Primiparous cows had a lower BCS during the early postpartum period and produced less milk than multiparous animals. Primiparous cows had higher NEFA concentrations and they presented more samples with BHB concentrations of $>1 \mathrm{mmol} / \mathrm{I}$ than multiparous cows. Multiparous cows had higher T3, T4 and IGF-I concentrations, while fat cows had higher leptin and IGF-I concentrations. All hormone concentrations were diminished in the first week postpartum. Primiparous cows and fat cows presented a steeper decay of IGF-I and leptin around parturition than multiparous cows and lean cows. While thyroid hormones and IGF-I showed increasing concentrations from approximately day 30, leptin concentrations remained low until the end of the experimental period. The initiation of ovarian cyclicity was delayed in primiparous cows and especially in primiparous lean cows, consistent with longer intervals from parturition to first service and to conception. The endocrine signals most likely to inform the reproductive axis regarding a negative energy balance were IGF-I and leptin.

Reproduction (2004) 127 727-737
\end{abstract}

\section{Introduction}

Genetic selection for milk production during the last decades has been associated with decreased reproductive efficiency (Lucy 2001). The resumption of ovarian cyclicity after parturition is closely related to the negative energy balance (EB) in this period; the time to the beginning of the recovery of the $\mathrm{EB}$ is positively correlated with the time to first ovulation (Butler et al. 1981). Butler \& Smith (1989) found that cows that lost less than 0.5 units of body condition score (BCS) during the first 5 weeks postpartum had higher conception rates at the first service than cows that lost more than 0.5 BCS. The physiological pathways by which the hypothalamic-pituitary-ovarian axis is informed about the energetic status of the animal are complex, and involve several metabolites and hormones, such as the growth hormone $(\mathrm{GH})$-insulin-like growth factor-I (IGF-I) system, insulin, thyroid hormones and leptin.
It has been proposed that the effect of negative EB on the resumption of ovulation may be mediated by the secretion of IGF-I (Spicer et al. 1990). Although GH concentrations are usually high in early lactating ruminants, the intrahepatic production of its mediator IGF-I is diminished (Chilliard 1999). Circulating concentrations of IGF-I in the peripartum period are good indicators of the capacity of energy-restricted cows to resume cyclicity after parturition (Roberts et al. 1997). Cows with ovulatory estrogen-active follicles have higher circulating IGF-I concentrations during the first 2 weeks than cows with anovulatory follicles (Beam \& Butler 1997, 1998). Both insulin and IGF-I are known to stimulate in vitro steroidogenesis and proliferation of bovine thecal and granulosal cell cultures (Spicer et al. 1993, Spicer \& Stewart 1996). Likewise, cows that ovulated within 35 days postpartum present higher IGF-I concentrations as well as higher glucose and insulin and lower non-esterified fatty acids 
(NEFA) and $\beta$-hydroxybutyrate (BHB) concentrations (Huszenicza et al. 2001).

Cows in postpartum negative EB have lower concentrations of thyroid hormones induced by altering central and peripheral mechanisms (Pethes et al. 1985, Capuco et al. 2001). A role of these hormones in regulating steroidogenesis has been reported (Spicer 2001), but data regarding their effect on ovarian function in vivo are limited and controversial (Huszenicza et al. 2002).

Leptin - secreted by the white adipose tissue - acts as an energy reserve signal for hypothalamic regions that control feeding behavior, metabolism and endocrine function so as to maintain energy homeostasis (Chilliard et al. 2001). In ruminants, as in other species, leptin concentrations vary with changes in body weight (BW) and percentage of body fat (Delavaud et al. 2002). Dairy cows often lose over $60 \%$ of their body fat during early lactation (Tamminga et al. 1997, Chilliard 1999), and it has been shown that the leptin concentration declines shortly before parturition (Kadokawa et al. 2000, Block et al. 2001, Liefers et al. 2003). There is less agreement on leptin concentrations after parturition: increasing (Kadokawa et al. 2000), unchanged (Huszenicza et al. 2001), diminished (Block et al. 2001, Holtenius et al. 2003) or a transient increase (Liefers et al. 2003) have been reported. The postpartum leptin reduction is likely to be due in part to the negative $\mathrm{EB}$ because plasma leptin remained high in cows not milked after parturition (Block et al. 2001).

There are only a few reports on the relation between leptin concentrations and resumption of cyclic ovarian activity during the postpartum period (Kadokawa et al. 2000, Huszenicza et al. 2001, Liefers et al. 2003). The interval from parturition to first ovulation correlated significantly with the interval from parturition to leptin nadir, but was not correlated with the prepartum, pre- and/or postovulatory leptin values (Kadokawa et al. 2000). Liefers et al. (2003) found that, although there was lack of relationship between leptin and first postpartum luteal activity, higher leptin concentrations were associated with shorter intervals to first observed estrus.

Although the physiological mechanisms that the dairy cow undergoes to adapt to lactation requirements should be basically similar among different productive systems, the energy demands due to grazing may modify the important transformations that take place during this period. Moreover, dry matter (DM) intake in these production systems is usually lower than in confined systems and may be insufficient to sustain the high milk production that can be achieved with the genetic potential (Kolver \& Muller 1998). Thus, the objective of this study was to characterize insulin, IGF-I, thyroid hormones and leptin concentrations of the transition cow along with $\mathrm{BHB}$ and NEFA profiles under grazing conditions. In addition, the effect of parity and BCS at parturition on endocrine and metabolite patterns and reproductive parameters were determined.

\section{Materials and Methods}

\section{Animals}

Holstein cows with two to five parturitions (multiparous cows, $n=21$ ) and cows without previous parturitions (primiparous cows, $n=21$ ) (average 305-day milk yield, 6000 and $4800 \mathrm{~kg}$ respectively) with normal parturitions during autumn (April) were selected from the herd of the experimental dairy farm of the Agronomy College (Paysandú, Uruguay). Animal experimentation was performed in compliance with regulations set by the Veterinary Faculty, University of Uruguay, Uruguay. Animals were grazing on improved pastures (mixture of grasses and legumes) and 3 weeks before parturition they were offered a diet that consisted of a mixture of $12 \mathrm{~kg}$ corn silage and $4 \mathrm{~kg}$ commercial concentrate (14\% crude protein (CP), 1.7 MCal net energy of location (Nel)/kg) which were given once a day, and bales of Setaria itálica ad libitum. After parturition, cows had access to a daily strip of pasture (mixture of grasses and legumes), $15 \mathrm{~kg}$ (fresh basis) corn silage (33\% DM, 6.8\% CP) and $6 \mathrm{~kg}$ DM of a commercial concentrate $(17 \% \mathrm{CP}, 1.7 \mathrm{MCal}$ net energy of lactation $(\mathrm{Nel}) / \mathrm{kg})$. The pasture sward mass $(1650 \pm 230 \mathrm{~kg}$ DM) was estimated with a comparative yield method adapted from Haydock \& Shaw (1975), and an allowance of 15-18 kg DM/cow per day was offered through weekly adjustments of the daily strip size. The cows had access to the grazing plot between the morning and the afternoon milking. The corn silage was fed in the afternoon (after milking), and the concentrate equally distributed during milking time (twice a day). Cows were milked twice a day and milk production was measured every 15 days. BCS was determined every 15 days by the same person from 2 months before until the third month after parturition using a scale from 1 (emaciated) to 5 (fat) according to Edmonson et al. (1989). Cows were scored to the nearest quarter point. At the same time, BW was determined. The BCS at parturition was determined by using the BCS closest to parturition. Animals were classified according to BCS at parturition in lean cows $(<3, n=20)$ or fat cows $(\geq 3, n=22)$; BCS was not induced by dietary treatment. Estrus was checked twice a day, and animals were inseminated $12 \mathrm{~h}$ after heat detection (voluntary waiting period $=50$ days). Reproduction was seasonal with a breeding period of 5 months (from May to September). Pregnancy diagnosis was performed by rectal palpation 45 days after artificial insemination. Blood samples were obtained three times a week, from around 30 days prepartum to 60 days postpartum. Blood was collected from the jugular vein in heparinized vials approximately $1 \mathrm{~h}$ after the morning milking (e.g. $1 \mathrm{~h}$ after the morning concentrate), centrifuged and plasma was stored at $-20^{\circ} \mathrm{C}$ until assayed. The reinitiation of ovarian cyclicity was determined by progesterone concentrations in plasma three times per week. Reproductive parameters measured were 
days to first ovulation, and intervals from parturition to first service and to conception.

\section{Metabolite and hormone determination}

BHB and NEFA were determined every 10 days from 1 month before to 2 months after parturition by a D-3hydroxybutyrate kit and a NEFA kit (Randox Laboratories Ltd, Crumlin, Co. Antrim, UK) respectively in the laboratory of the Research Institute for Animal Husbandry and Nutrition, Herceghalom, Hungary. The intra-assay coefficients of variation (CV) for BHB and NEFA were $\leq 5.5 \%$ and $\leq 4.5 \%$ and the interassay $\mathrm{CV}$ values were $\leq 7.3 \%$ and $\leq 9.7 \%$ respectively.

Total plasmatic proteins, albumin, urea, cholesterol, calcium, magnesium, phosphorus and aspartate aminotransferase were determined by commercial kits from Weiner Laboratory (Rosario, Argentina) on a Vitalab Spectra 2 autoanalyzer (Vital Scientific NV, Dieren, The Netherlands). All samples were assayed in two assays at the laboratory Miguel C Rubino, Dirección Laboratories Veterinarios, Pando, Uruguay. The intra-assay CV was $\leq 3.7 \%$ for all the parameters, and the interassay $\mathrm{CV}$ was $\leq 9.6 \%$. The data for these metabolites, although used in some statistical analyses, are not shown.

Progesterone was determined three times per week in all plasma samples from parturition (day 0) until around 70 days postpartum (range 58-84 days). Concentrations of all other hormones were determined approximately every 10 days from 1 month before to 2 months after parturition. Progesterone was determined in the Biochemistry Laboratory, Faculty of Veterinary Medicine, Uruguay. All other hormone determinations were assayed in the Endocrine Laboratory of the Faculty of Veterinary Science, Budapest, Hungary.

Progesterone was determined with a commercial kit (Coat-a-count; DPC Diagnostic Products Co., Los Angeles, CA, USA). The intra- and interassay $\mathrm{CV}$ values were $6 \%$ and $11 \%$. The sensitivity was $0.1 \mathrm{nmol} / \mathrm{l}$.

Thyroxine (T4) and 3,3',5-tri-iodothyronine (T3) were determined by ${ }^{125} \mathrm{I}$-Spec RIA coated tube kit (Institute of Isotopes Co. Ltd, Budapest, Hungary). The sensitivity was $0.5 \mathrm{nmol} / \mathrm{l}$ (T4) and $0.19 \mathrm{nmol} / \mathrm{l}$ (T3). The intra-assay CV values were $6.4-8.1 \%$ for T4 and $6.0-8.3 \%$ for T3. The interassay $\mathrm{CV}$ values were $\leq 5.8 \%$ and $\leq 6.5 \%$ respectively.

Insulin was determined by a ${ }^{125}$ I-insulin RIA CT kit (CIS Bio International Ltd, Gif-Sur-Yvette, France). The sensitivity of the assay was $1.08 \mu \mathrm{U} / \mathrm{ml}$. The intra-assay $\mathrm{CV}$ ranked $5.5-8.4 \%$, while the interassay $\mathrm{CV}$ was $\leq 8.8 \%$.

IGF-I was determined in neutralized acid-ethanol extracts of plasma using a ${ }^{125}$ I-IGF RIA validated for bovine samples (Nikolić et al. 2001). Since the amino acid composition of bovine and human IGF-I is the same, human IGF-I was used as the working standard in the presence of human IGF-II (4 ng/tube). Human IGF-I (ICN Biomedicals Inc., Aurora, OH, USA) labeled with ${ }^{125}$ I was used as the tracer and polyclonal rabbit antibodies to human IGF-I (Biogenesis, Poole, Dorset, UK) as the reagent. The intraassay $\mathrm{CV}$ values for duplicate samples were routinely from $3 \%$ to $6 \%$. Interassay CV values were below $12 \%$.

Plasma leptin concentration was quantified in accordance with our earlier report in ewes (Kulcsar et al. 2004). This assay system is a local version of the ovine-specific homologue ${ }^{125}$ I RIA of Delavaud et al. (2000) which was validated for bovine species (Delavaud et al. 2002). Under routine use, the sensitivity of this assay for bovine plasma is $0.03 \mathrm{nmol} / \mathrm{l}$. The inter- and intra-assay $\mathrm{CV}$ values were $12.0,5.5$ and $6.0 \%$, and $10,4.5$ and $5.2 \%$ for the low, medium and high quality control samples respectively.

\section{Statistical analyses}

Milk production, BCS, metabolites and hormonal concentrations were analyzed by a mixed procedure (Statistical Analysis System; SAS Institute Inc., Cary, NC, USA). The statistical model included the effects of parity (categories: primiparous $=\mathrm{L} 1$ or multiparous $=\mathrm{L} 2$ ), BCS at parturition (BCS $<3$ or $\geq 3$ ), days including pre- and postpartum periods (linear and quadratic functions) and interactions. The covariance structure was autoregressive order 1 and cow within parity $\times$ BCS at parturition was set as the random effect. Functions were calculated for each dependent variable and differences in the estimates of the curves were analyzed according to parity and BCS at parturition. Postpartum days were categorized in intervals of 10 days during the experimental period (day $0=$ day of parturition) and data are presented in the Figures as least square means \pm pooled standard error. To study reproductive parameters, a general linear model was used and the fixed effects were parity and BCS at parturition. Tukey-Kramer tests were conducted to analyze differences between groups. The reinitiation of ovarian cyclicity was defined as the day when progesterone increased from basal concentrations in two consecutive samples of $>1.6 \mathrm{nmol} / \mathrm{l}$ or one sample of $>3.2 \mathrm{nmol} / \mathrm{l}$. If no detectable progesterone was observed until around day 70 postpartum, the last day of sampling was arbitrarily considered as the initiation of ovarian cyclicity for that cow. Correlation coefficients were calculated to study relationships between variables (correlation procedure of SAS). Factors affecting the reinitiation of ovarian cyclicity were evaluated by regression analysis using a backwards elimination procedure (initial inclusion of all independent variables and sequential elimination of the variables with $P>0.10$ using the regression procedure of SAS) to determine those with $P$ values $<0.10$. The dependent variable was the reinitiation of ovarian cyclicity and the independent variables included were parity, BCS at parturition, BW, body condition, milk production, total protein, albumin, urea, NEFA, BHB, cholesterol, aspartate aminotransferase, calcium, phosphorus, magnesium, insulin, T3, T4, IGF-I and leptin. The last observation before the reinitiation of ovarian cyclicity in each cow was included in this study. Regression 
analyses were performed to study the relationships between leptin and BCS, leptin and NEFA and leptin and IGF-I before and after parturition in cows with low and high BCS at parturition.

\section{Results}

\section{Milk production}

Primiparous cows produced less milk than multiparous cows during the experimental period (Tukey-Kramer, $P<0.001$, Fig. 1). Milk production was affected by days postpartum (Table 1). Milk production was negatively correlated with body condition and with NEFA $(r=-0.35$, $n=165, \quad P<0.05$ and $r=-0.24, \quad n=165, \quad P<0.05$ respectively).

\section{$B W$ and $B C S$}

The loss of body condition is shown in Fig. 2. Lean cows (BCS at parturition <3.0) had a smaller BCS during the

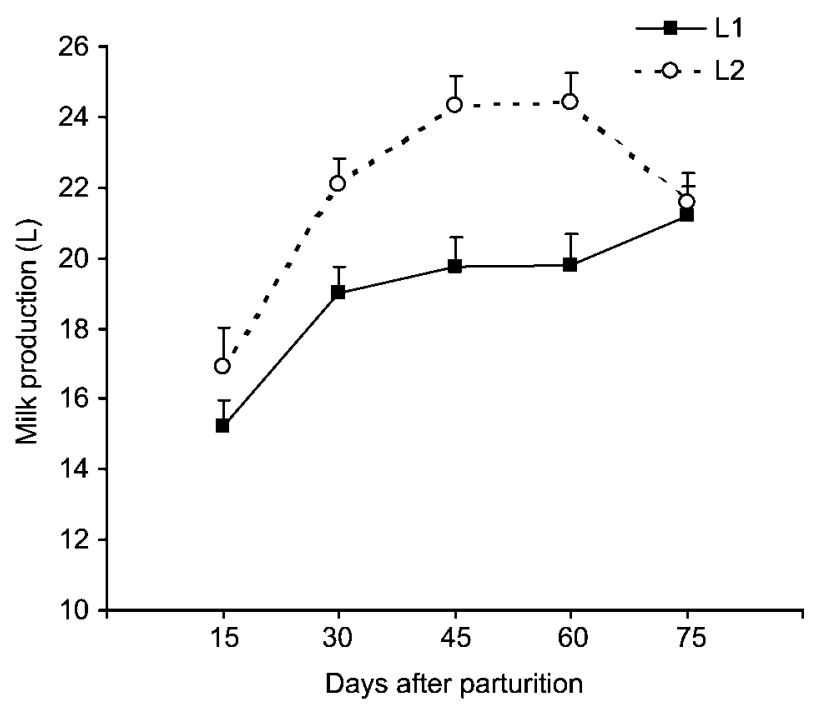

Figure 1 Milk production (means \pm S.E.M.) of primiparous (lactation 1, $\mathrm{L} 1, n=21$ ) and multiparous (lactation 2, L2, $n=21$ ) cows under grazing conditions. experimental period, while fat cows $(\geq 3.0)$ tended to lose more BCS. BCS was affected by parity and days postpartum, with an interaction between both effects (Table 1). Primiparous cows had a steeper decline in BCS than multiparous cows but they recuperated faster (Table 2). BCS was negatively correlated with NEFA and BHB $(r=-0.35, n=298, P<0.05$ and $r=-0.17, n=295$, $P<0.05$ respectively).

Multiparous cows had a higher BW than primiparous cows (576 \pm 7 vs $510 \pm 7 \mathrm{~kg}, P=0.0001)$. Parity and BCS at parturition affected BW changes during the experimental period. Statistical differences were found on the drop in BW (kg/day: -1.7 , primiparous vs -1.3 , multiparous) but not on its recuperation (Table 2). A strong correlation between BW and BCS was found for primiparous cows $(r=0.7624, n=146, P<0.0001)$ and multiparous cows $(r=0.7416, n=145, P<0.0001)$.

\section{NEFA and BHB profiles}

NEFA concentrations started to increase before parturition; in primiparous cows they reached peak concentrations at day 20 and in multiparous cows at day 14 and started to decrease thereafter (Fig. 3). The increase observed in NEFA concentrations was higher for primiparous cows and levels remained high for a longer period (Table 2). $\mathrm{BHB}$ concentrations were low at parturition, rose sharply to approximately day 10 and slowly decreased thereafter (Fig. 3). When BHB values of $>1 \mathrm{mmol} / \mathrm{l}$ were considered (cows with subnormal levels according to Whitaker et al. (1999)) primiparous cows had more samples with these levels $(P<0.05)$. NEFA and BHB levels were highly correlated $(r=0.53, n=441, P<0.001)$.

\section{Insulin}

Insulin concentrations differed according to days postpartum: levels started to decrease before parturition, minimum concentrations were found around parturition but levels were fully recovered at day 30 postpartum (Fig. 4A). There was no effect of parity or BCS at parturition on insulin concentrations (Table 1).

Table 1 F-tests of fixed effects included in the model for measured parameters in cows under grazing conditions. Fixed effects are the effects of parity $(\mathrm{P}), \mathrm{BCS}$ at parturition (BCS-C), days postpartum (linear (DPP) and quadratic functions (DPP $\left.{ }^{2}\right)$ ) and interactions between them.

\begin{tabular}{|c|c|c|c|c|c|c|c|c|c|c|}
\hline Variable & $n$ & $\boldsymbol{P}$ & BCS-C & DPP & $\mathrm{DPP}^{2}$ & $P \times B C S-C$ & $\mathbf{D P P} \times \mathbf{P}$ & $\mathrm{DPP} \times \mathrm{BCS}-\mathrm{C}$ & $\mathrm{DPP}^{2} \times \mathbf{P}$ & $\mathrm{DPP}^{2} \times \mathrm{BCS}-\mathrm{C}$ \\
\hline BCS & 328 & 0.07 & $* * *$ & $* * *$ & $* * *$ & 0.11 & $* * *$ & 0.11 & & 0.08 \\
\hline BW & 292 & $* * *$ & $*$ & $* * *$ & $* * *$ & & $*$ & 0.10 & & \\
\hline Milk & 165 & & & $* * *$ & $* * *$ & & & & & \\
\hline NEFA & 446 & 0.11 & & $* * *$ & $* * *$ & & $* * *$ & & $* *$ & \\
\hline $\mathrm{BHB}$ & 441 & & & $*$ & $*$ & & 0.07 & & 0.08 & \\
\hline Insulin & 446 & & & $*$ & $* * *$ & & & & 0.09 & \\
\hline $\mathrm{T} 4$ & 446 & 0.10 & & $* * *$ & $* * *$ & & & & & \\
\hline T3 & 446 & $*$ & & $* * *$ & $* * *$ & & & & & \\
\hline IGF-I & 446 & $* * *$ & $*$ & $* * *$ & $* * *$ & & $* *$ & $* *$ & $* * *$ & 0.09 \\
\hline Leptin & 446 & 0.13 & $* *$ & $* * *$ & $* * *$ & & 0.07 & 0.07 & & \\
\hline
\end{tabular}

$* P<0.05, * * P<0.01, * * * P<0.001$. 


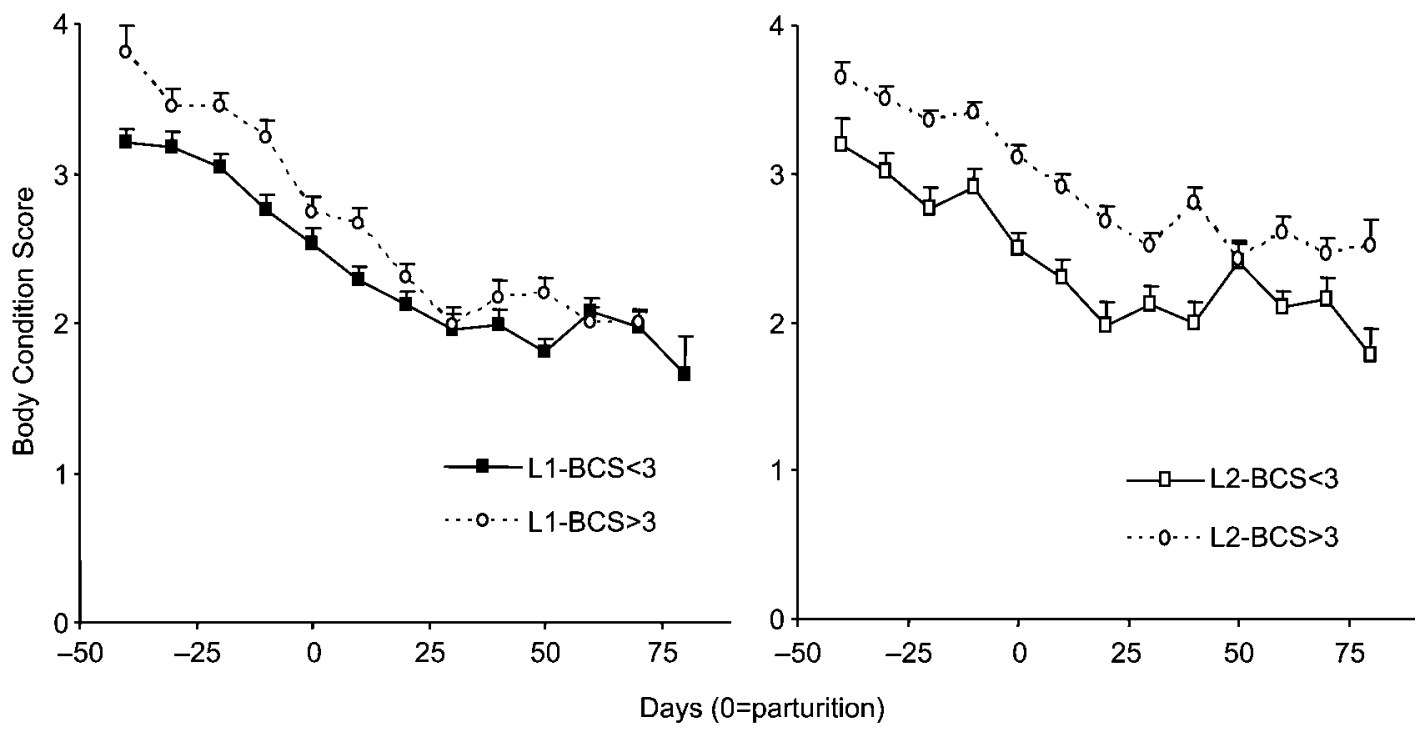

Figure 2 Evolution of BCS (means \pm S.E.M.) in lean (L1-BCS $<3, n=12)$ and fat (L1-BCS $\geq 3, n=9$ ) primiparous cows and lean (L2-BCS $<3$, $n=8$ ) and fat (L2-BCS $\geq 3, n=13$ ) multiparous cows.

Table 2 Estimates of the functions in primiparous and multiparous cows. Only variables with significant differences according to parity are presented.

\begin{tabular}{|c|c|c|c|c|c|c|}
\hline \multirow[b]{2}{*}{ Variable (unit) } & \multicolumn{3}{|c|}{ Primiparous cows } & \multicolumn{3}{|c|}{ Multiparous cows } \\
\hline & Intercept & DPP & $\mathrm{DPP}^{2}$ & Intercept & DPP & $\mathrm{DPP}^{2}$ \\
\hline BCS (scale 1-5) & $2.61^{\mathrm{a}}$ & $-0.01861^{\mathrm{a}}$ & $0.00013^{a}$ & $2.75^{\mathrm{b}}$ & $-0.01284^{b}$ & $0.00008^{b}$ \\
\hline $\mathrm{BW}(\mathrm{kg})$ & $521^{\mathrm{a}}$ & $-1.6933^{\mathrm{a}}$ & 0.009153 & $583^{\mathrm{b}}$ & $-1.3286^{\mathrm{b}}$ & 0.005954 \\
\hline $\mathrm{NEFA}(\mathrm{mmol} / \mathrm{l})$ & 0.42 & $0.0039^{\mathrm{a}}$ & $-0.00010^{\mathrm{a}}$ & 0.39 & $0.0017^{\mathrm{b}}$ & $-0.00006^{\mathrm{b}}$ \\
\hline IGF-I $(\mathrm{nmol} / \mathrm{l})$ & $3.81^{\mathrm{a}}$ & $-0.039^{\mathrm{a}}$ & $0.000884^{\mathrm{a}}$ & $4.52^{\mathrm{b}}$ & $-0.0247^{b}$ & $0.000559^{b}$ \\
\hline Leptin (nmol/l) & $0.40^{\mathrm{a}}$ & $-0.00312^{x}$ & 0.0000479 & $0.431^{\mathrm{b}}$ & $-0.0025^{y}$ & 0.0000398 \\
\hline
\end{tabular}

Values with different superscripts within estimates (intercept, DPP and DPP 2$)$ differ according to parity $(P<0.05)$. $\mathrm{x}$ vs $\mathrm{y}$ differ $(P=0.066)$.

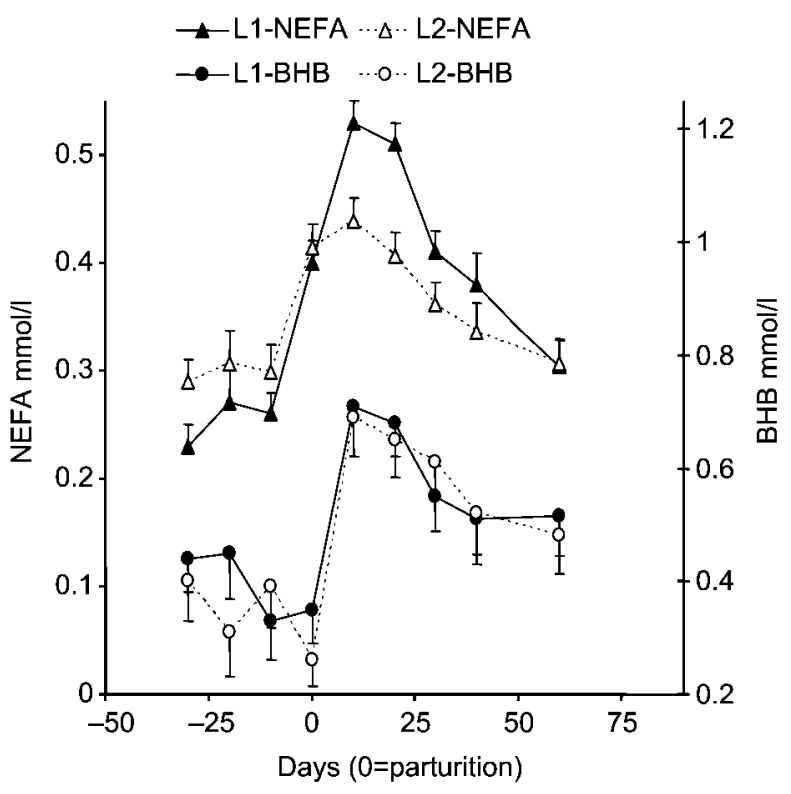

Figure 3 Levels (least square means \pm S.E.M.) of NEFA and BHB in cows under grazing conditions $(n=42)$.

\section{Thyroid hormones}

Both hormones were affected by days postpartum (Table 1) but no other effect was found and parallel curves could be observed in both categories (Fig. 4B). Concentrations started to decrease before parturition and minimum levels were found soon after parturition. Thyroid hormones did not recover prepartum concentrations until the end of the study. Multiparous cows had higher T3 concentrations than primiparous cows $(1.36 \pm 0.03$ vs $1.23 \pm 0.03 \mathrm{nmol} / \mathrm{l})$, and T4 concentrations tended to be different ( $43 \pm 1.8$ vs $39.4 \pm 1.7 \mathrm{nmol} / \mathrm{l}, P<0.1)$.

\section{IGF-I}

Effects of parity and BCS at parturition were found in IGF-I concentrations; primiparous cows and lean cows had lower concentrations of IGF-I (Fig. 5A and B). Concentrations of IGF-I started to decrease 20 days before parturition in all cows to reach half of the prepartum values after parturition. The curves of IGF-I concentration differed according to category (Table 2); primiparous cows had a steeper decrease than multiparous cows, remained 


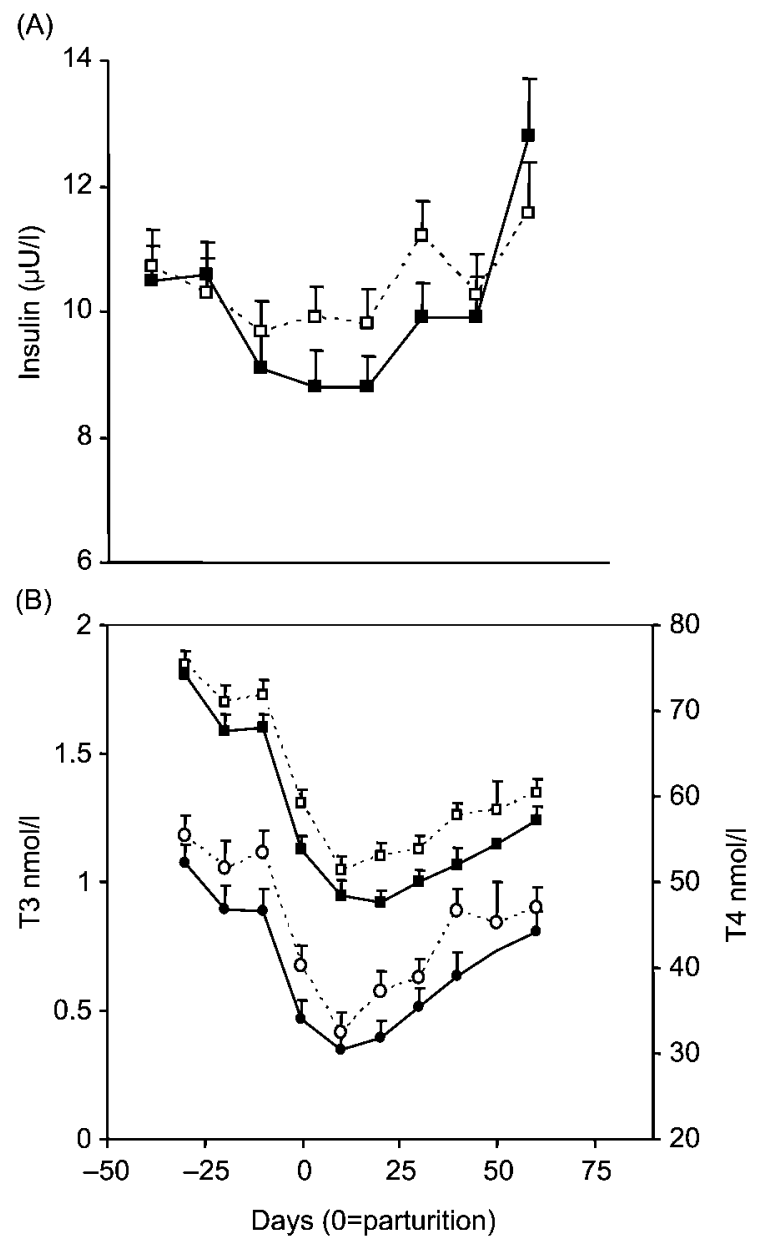

Figure 4 Concentrations (least square means \pm S.E.M.) of (A) insulin (Ins) and (B) T4 and T3 in primiparous (L1, $n=21)$ and multiparous $(\mathrm{L} 2, n=21)$ cows under grazing conditions. (A) L1-Ins $(\mathbf{\square}), \mathrm{L} 2-\operatorname{Ins}(\square)$

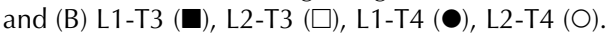

lower for more days but they tended to recover IGF-I concentrations faster (Fig. 5A and B). There was also an interaction between BCS at parturition and days postpartum: IGF-I (nmol/l) in fat cows fell more sharply than in lean cows $\left(4.36^{\mathrm{a}}-0.039^{\mathrm{a}} \mathrm{x}+0.00078^{\mathrm{y}} \mathrm{x}^{2}\right.$ vs $3.96^{\mathrm{b}}-0.026^{\mathrm{b}} \mathrm{x}+0.00065^{z} \mathrm{x}^{2}, P<0.05 ;$ a vs $b, P<0.05$; y vs $z, P=0.094)$.

\section{Leptin}

Leptin levels decreased sharply before parturition and in contrast with the pattern of the other hormones - concentrations remained low during the sampling period (Fig. 5C and D). BCS at parturition affected leptin concentrations (Table 1). Leptin concentrations (nmol/l) during late pregnancy and the first 2 weeks of lactation were higher in cows with higher BCS. Leptin concentrations in primiparous cows tended to present a steeper peripartum decay than multiparous cows, $P=0.066$ (Fig. 5C and D and Table 2) and reached a lower level postpartum $(P<0.01)$. Fat cows presented a steeper peripartum decay when compared with lean cows $\left(0.444^{a}-0.00312^{y} x+\right.$
$0.00005 x^{2}$ vs $0.387^{b}-0.0025^{z} x+0.000044 x^{2}, P<0.05$; a vs $b, P<0.05$; y vs $z, P=0.073$ ). The leptin nadir in lean cows was reached 10 days before that in fat cows. Furthermore, plasma leptin at 10 days of lactation was much lower in lean than fat heifers (Fig. 5C).

\section{Correlations among variables}

T4, T3, IGF-I and leptin were correlated with BCS; the latter presented the highest correlation coefficient $(r=0.51$, $r=0.68, \quad r=0.61$ and $r=0.8$ respectively, $n=292$, $P<0.001$ for all). Milk production was associated with T3 and with a higher significance to IGF-I $(r=0.22$, $n=152, \quad P<0.05$ and $r=0.26, \quad n=152, \quad P<0.01$ respectively). All hormones were negatively correlated with NEFA and BHB and high correlation coefficients for NEFA vs T3 $(r=-0.67, n=446, P<0.001)$ and NEFA vs IGF-I $(r=-0.7, n=446, P<0.001)$ were found. All hormone concentrations were positively correlated and T3 vs T4 $(r=0.83, n=446, P<0.001)$, T3 vs IGF-I $(r=0.78$, $n=446, P<0.001)$ and IGF-I vs leptin $(r=0.7, n=446$, $P<0.001)$ were the ones most closely related.

\section{Regression analyses}

The regression analyses between plasma leptin and BCS before and after parturition in lean and fat cows are shown in Fig. 6. While leptin concentrations were consistently related to BCS during the experimental period in fat cows this was present only before parturition in lean cows.

Plasma leptin concentration $(\mathrm{nmol} / \mathrm{l})$ was less related to NEFA concentration in fat than in lean cows, either before or after parturition (fat cows: $y=0.669-0.431 x, n=91$, $\mathrm{R}^{2}=0.14$ or $\mathrm{y}=0.444-0.125 \mathrm{x}, \quad n=156, \mathrm{R}^{2}=0.05$; lean cows: $y=0.612-0.538 x, n=70, R^{2}=0.32$ or $y=0.444-0.194 x, \quad n=129, \quad R^{2}=0.21 \quad$ respectively, $P<0.005$ for all).

Similar observations occurred when analyzing leptin vs IGF-I concentration. The functions for fat cows were $\mathrm{y}=0.325+0.005 \mathrm{x}, \quad n=91, \quad \mathrm{R}^{2}=0.19$ before parturition and $y=0.25+0.0038 x, n=156, R^{2}=0.2$ after parturition; lean cows $y=0.125+0.0088 x, n=70$, $\mathrm{R}^{2}=0.51$ and $\mathrm{y}=0.238+0.0044 \mathrm{x}, n=129, \mathrm{R}^{2}=0.33$, $P<0.0001$ for all).

\section{Reproductive parameters}

There was an effect of parity on the initiation of ovarian cyclicity, parturition to first service and parturition to conception intervals. The interaction effect of BCS at parturition and parity was significant only for the reinitiation of ovarian cyclicity (Table 3 ). Postpartum anestrus was longer in primiparous than in multiparous cows: 45 vs 21 days $(P<0.0001)$. Primiparous lean cows presented a longer interval from parturition to first ovulation than primiparous fat cows, but this was not observed for multiparous cows. 
(A)

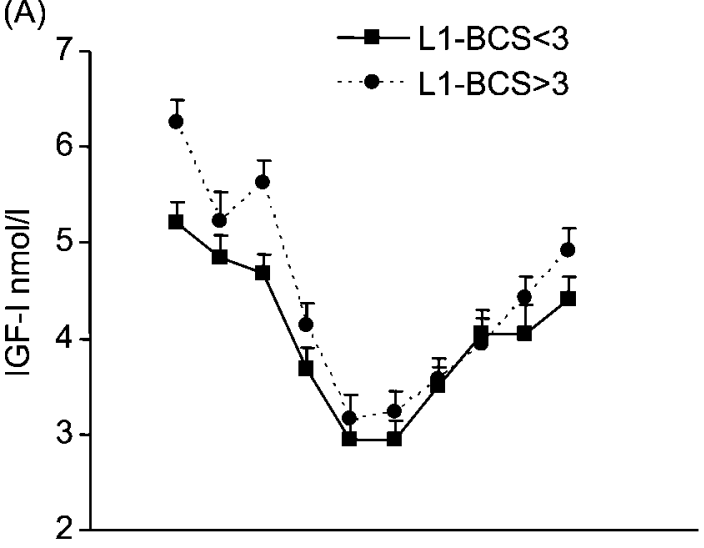

(C)

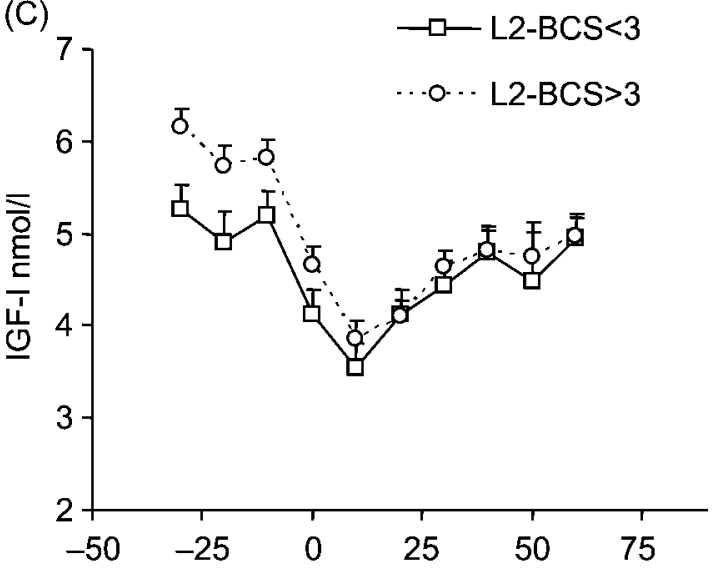

(B)

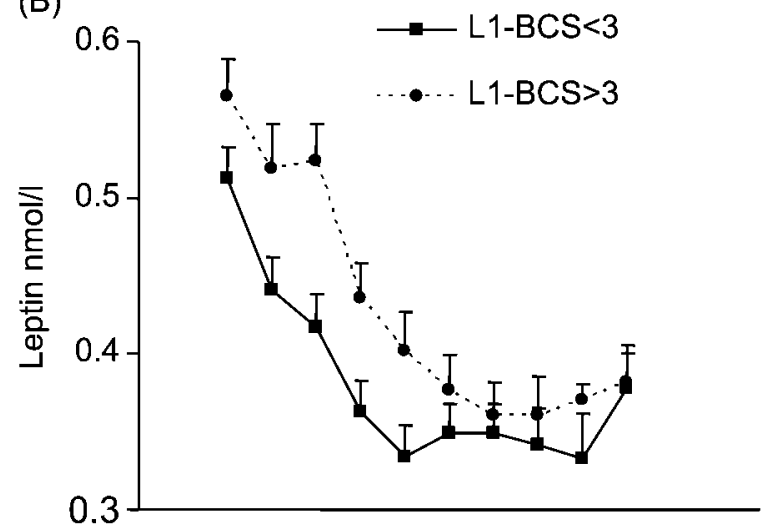

(D)

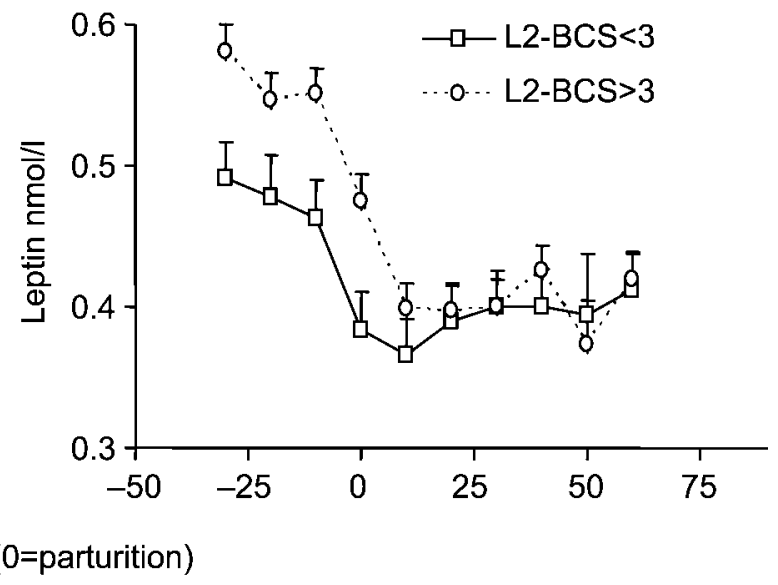

Figure 5 Concentrations (least square means \pm S.E.M.) of IGF-I and leptin in lean (L1-BCS $<3, n=12)$ and fat (L1-BCS $\geq 3, n=9)$ primiparous cows and lean (L2-BCS $<3, n=8$ ) and fat (L2-BCS $\geq 3, n=13$ ) multiparous cows.

Table 3 Mean \pm S.E.M. days to first ovulation, parturition first service interval and parturition conception interval in primiparous (L1) or multiparous (L2) cows with BCS at parturition of $<3$ or $\geq 3$. Numbers are shown in parentheses.

\begin{tabular}{lcrr}
\hline Parity/BCS at parturition & First ovulation & Parturition first service interval & Parturition conception interval \\
\hline L1/BCS $<3(12)$ & $52.8^{\mathrm{a}} \pm 4.8(12)$ & $139.0^{\mathrm{d}} \pm 11.8(10)$ & $143.0^{\mathrm{gh}} \pm 13.0(8)$ \\
L1/BCS $\geq 3(9)$ & $37.4^{\mathrm{b}} \pm 5.6(9)$ & $122.2^{\mathrm{de}} \pm 12.8(9)$ & $149.4^{\mathrm{g}} \pm 12.2(8)$ \\
L2 BCS $<3(8)$ & $19.0^{\mathrm{c}} \pm 6.3(8)$ & $99.9^{\mathrm{ef}} \pm 13.7(8)$ & $114.1^{\mathrm{hi}} \pm 13.0(8)$ \\
L2/BCS $\geq 3(13)$ & $23.0^{\mathrm{c}} \pm 4.5(13)$ & $93.4^{\mathrm{f}} \pm 10.0(11)$ & $104.0^{\mathrm{i}} \pm 10.0(11)$ \\
\hline
\end{tabular}

Values with different letters within the same column differ $(P<0.05)$ except e vs $\mathrm{f}(P=0.085)$ and $\mathrm{g}$ vs $\mathrm{h}(P=0.058)$.

Overall, the interval from parturition to first service was 131 and 97 days for primiparous and multiparous cows respectively $(P<0.01)$. The interval from parturition to conception was 146 and 109 days for primiparous and multiparous cows $(P<0.01)$. An interesting finding was that multiparous lean cows reinitiated ovarian cyclicity before the primiparous fat cows. This was reflected in the parturition to conception interval (Table 3).

BCS at parturition, BCS, insulin, leptin, BHB and total protein (all with $P<0.05)$ and urea and T3 $(P<0.08)$ were associated with the reinitiation of ovarian cyclicity as determined by regression analysis $\left(R^{2}=0.78, P=0.0001\right)$.

\section{Discussion}

This study has demonstrated that parity affects NEFA, T3, T4 and IGF-I concentrations as well as reproductive parameters in dairy cows, while BCS at parturition has an effect on IGF-I and leptin concentrations and reproductive parameters.

Body condition decreased from 30 days before parturition, and this trend was steeper during the first 4 weeks after parturition. NEFA and BHB levels increased around parturition, reflecting the negative EB of the animals (Ingvarsten \& Andersen 2000). Primiparous cows had lower BCS than multiparous cows and this was consistent 

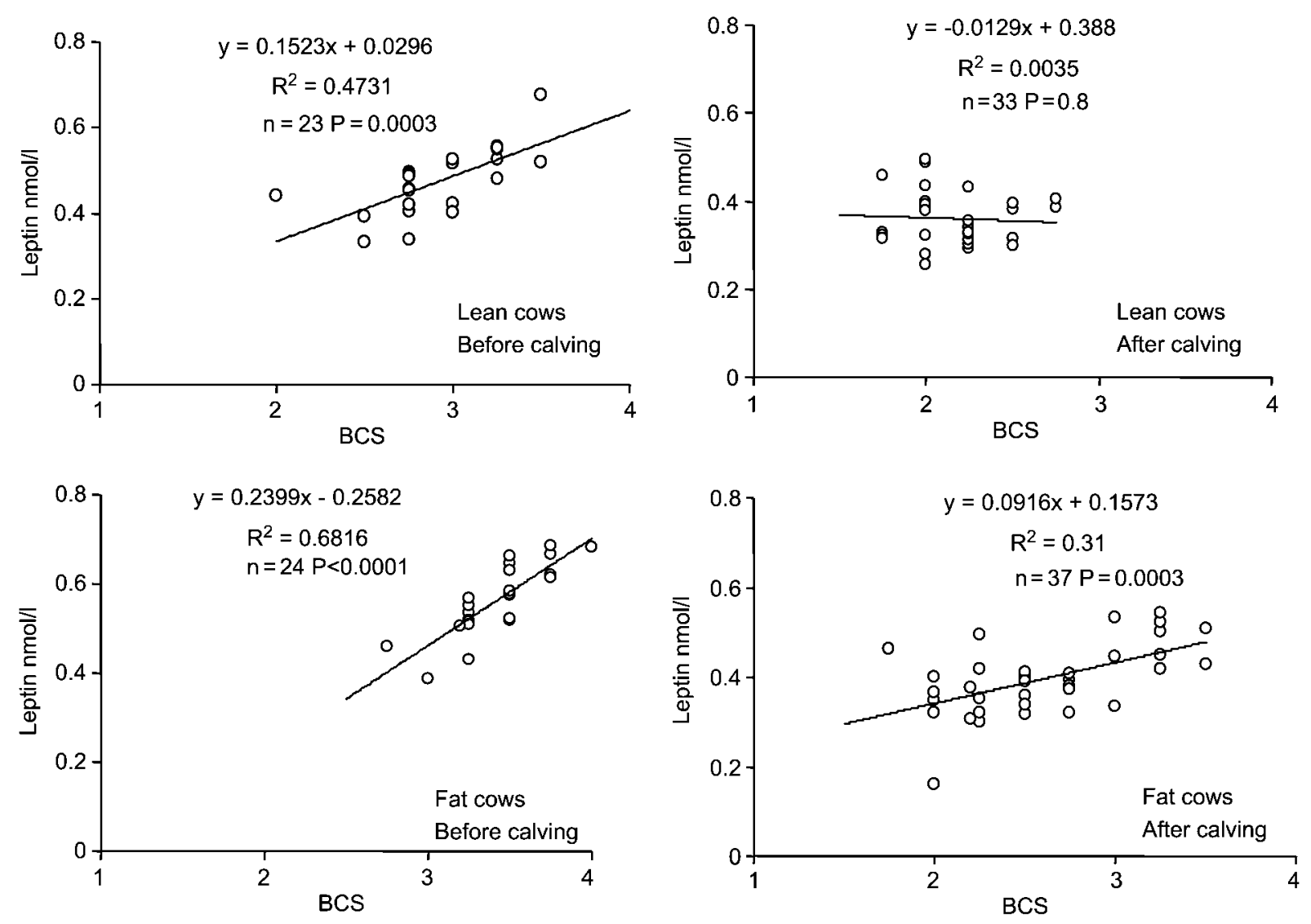

Figure 6 Relationships between plasma leptin and BCS in lean or fat dairy cows (i.e. with BCS at parturition of BCS $<3$ or BCS $\geq 3$ respectively) measured either 1 month before or 2 months after parturition.

with the higher NEFA levels and the greater number of BHB samples above $1 \mathrm{mmol} / \mathrm{l}$ in this category (subclinical ketosis according to Whitaker et al. (1999)). This is probably related to the increased needs for growth in primiparous cows occurring simultaneously with the demands of lactation and their lower feed intake capacity as described previously (Rémond et al. 1991).

Studies investigating the potential metabolic signals for the reproductive axis have been focused primarily on blood metabolites and metabolic hormones known to fluctuate during altered states of energy metabolism. Decreased insulin concentrations around parturition were found in agreement with previous reports (Holtenius et al. 2003). Insulin plays a central role in the homeostatic control of energy metabolism and its concentration is positively correlated with energy intake (Chilliard et al. 1998). The diminished concentration is consistent with the reduction in DM intake that characterizes this period (Bertics et al. 1992). Both insulin and IGF-I are known to stimulate follicular growth (Spicer et al. 1993), but in this study insulin did not seem to be related to reinitation of ovarian cyclicity: insulin concentrations were fully recovered 30 days postpartum and while multiparous cows ovulated before that period, primiparous cows ovulated afterwards.
The peripheral tissues try to fit their current local energy metabolism to the postpartum catabolic condition, for example by interfering in the path of thyroid hormones, resulting in diminished circulation as observed here as well by others (Pethes et al. 1985, Heyden et al. 1993). Lower concentrations of T3 were found in primiparous cows which is in disagreement with the data of Cissé et al. (1991) who suggested that higher T3 concentrations in the first lactation could be due to a lower milk yield since thyroid hormones are excreted by the mammary gland. On the other hand, a lower level of T3 was reported to be associated with lower EB (Blum et al. 1983), which seems to be the case in our study when taking into account the fact that primiparous cows presented comparatively greater body condition loss and an overall unbalanced metabolic condition. This could explain the apparent discrepancy with the study of Cissé et al. (1991), in which heifers and cows had the same EBs. Low thyroid hormone concentrations have been suggested to be associated with low reproductive performance in the postpartum cow (Huszenicza et al. 2002).

In our study, parity affected IGF-I concentrations as primiparous cows had lower concentrations of this hormone. This contrasts with previous findings (Wathes et al. 2003) where IGF-I concentrations were higher in 
the younger animals. Since it has been suggested that low insulin and IGF-I are the metabolic signals that delay ovulation (Beam \& Butler 1999) and IGF-I concentrations were high in primiparous cows, Taylor et al. (2003) suggested that in this category - which is still growing - insulin concentrations may be limiting, whereas in older cows a closer association is observed between IGF-I and fertility parameters. Our results do not support this hypothesis since primiparous cows presented lower IGF-I but similar insulin concentrations and presented a delayed ovulation when compared with multiparous cows. Primiparous cows with lower mean IGF-I concentrations presented a steeper decline in IGF-I than multiparous cows. Lean cows with lower IGF-I concentrations than fat cows presented a slower decline. IGF-I concentrations are good indicators of the capacity to resume cyclicity after parturition in agreement with Roberts et al. (1997): fat cows and multiparous cows had higher IGF-I concentrations and better reproductive performance.

As previously reported in adult dry non-pregnant ruminants (Delavaud et al. 2000, 2002), plasma leptin content in this study was a good indicator of body fatness (BCS) in peripartum dairy cows, especially when measured 3 weeks before calving, i.e. at a stage where leptin is highly expressed. On the other hand, Holtenius et al. (2003) reported no relation between leptin concentrations and BCS after parturition. Differences among studies could be due to the different production system, energy intake, EB, range of BCS among cows, genetic background and/or frequency of sampling. Leptin concentrations started to decrease by 20 days before parturition in agreement with other studies (Kadokawa et al. 2000, Block et al. 2001, Liefers et al. 2003) and then remained low until 2 months after parturition which is at variance with the reported increase around day 10 postpartum (Kadokawa et al. 2000), the progressive increase from week 1 to week 12 (Reist et al. 2003), the unchanged concentrations up to week 5 (Huszenicza et al. 2001) and the transient increase at week 2 (Liefers et al. 2003), but consistent with the lower concentrations found by Block et al. (2001) and Holtenius et al. (2003). Baseline leptin levels were reached later postpartum in fat cows consistent with a later maximal loss in BCS in these animals, suggesting that the decrease in leptin concentrations due to negative EB may be masked in fat cows by the amount secreted by the adipose tissue reserves that are still high during the first month of lactation. This hypothesis is supported by the regression analyses of plasma leptin during the pre- and postpartum period in lean and fat cows: while no association was found between leptin levels and BCS after parturition in lean cows, this was maintained in fat cows during the same period. Overall, our results suggest interactions between the effects of BCS, parity and lactation stage on peripartum leptin regulation.

The reinitiation of ovarian cyclicity was delayed in primiparous cows and in lean animals and this was consistent with longer intervals from parturition to first service and to conception in these animals. The anestrous duration was associated with BCS loss and was longer in primiparous cows as shown previously (Butler \& Smith 1989). These authors and others (Huszenicza et al. 1987, 1988) demonstrated that the sooner the cows restore the $E B$, the sooner they will start cycling and become pregnant. It is interesting to note that multiparous lean cows resumed cyclic activity sooner than primiparous fat cows and this could be due to the patterns of the endocrine signals or to negative EB due to lower intake, ascendant lactation curve (Fig. 1) and/or growth requirements in heifers. All these parameters could indeed be related to the high body lipid mobilization (Verité \& Chilliard 1992), BCS loss (Rémond et al. 1991) and higher plasma NEFA (Cissé et al. 1991, Fig. 3) that were observed in primiparous cows vs multiparous cows, despite the fact that the former yielded less milk. In this study, parity was a more important effect for reproductive performance than BCS at parturition; it should be noted that these animals were under grazing conditions where an effect such as dominance for food availability is present (Grant \& Albright 2001).

Cows with better reproductive performance had higher IGF-I and leptin concentrations. Similarly, a negative relationship between IGF-I concentrations after parturition and the interval to the resumption of ovarian cyclicity has been reported (Butler 2000). Data regarding leptin and reproductive performance are conflicting. Cows with decreased leptin have been linked to delayed onset of cyclicity or longer intervals to first estrus during the postpartum period (Kadokawa et al. 2000, Liefers et al. 2003). Similarly, a slightly increasing tendency of the leptin pattern was seen in cows resuming their ovarian cyclicity within 35 days (Huszenizca et al. 2001). The data presented here do not support the theory that the restoration in leptin concentrations activates the hypothalamic-pituitary-ovarian axis since, unlike the other hormones, it remained low until 60 days postpartum. On the other hand, not only are the hormone concentration itself and the tissue sensitivity to it (receptors) important for the reproductive axis, but also the hormonal dynamics (e.g. leptin decay - as for IGF-I - was more precipitous in primiparous cows) could be read by the endocrine system as a different signal. As previously reported (Bocquier et al. 1998, Clarke \& Henry 1999) our results also suggest that leptin may play a permissive role, when increased above a critical threshold, in the activation of the hypothalamus-pituitary axis and consequent reinitation of ovarian activity in the postpartum cow. This would allow cows which are in good condition at parturition and thus have a higher leptinemia during early lactation (Fig. 5), to have a facilitated reproductive activity.

In summary, primiparous cows showed a metabolic/endocrine profile more unbalanced than that of multiparous cows, reflecting that they are recovering from the negative EB period with more difficulty. The endocrine signals that 
could most likely inform the reproductive axis with regard to the negative EB and/or the level of body reserves that may explain the reproductive performance found in this study were IGF-I and leptin.

\section{Acknowledgements}

The authors would like to thank Dr Gy Huszenicza and Dr M Boland for constructive criticism of this manuscript and Dr M B Hall for statistical advice. We thank J Herrmann and $G$ Rupretcher for technical assistance and the authorities of the Estación Experimental Mario A Cassinoni, Agronomy Faculty for providing the animals and infrastructure. The present study received financial support from ECOS program $\mathrm{N}^{\circ}$ U03B02 to Unité de Recherche sur les Herbivores, INRATheix, France; Veterinary Faculty, Uruguay, Comisión Sectorial de Investigación Cientifica, University of Uruguay, the International Foundation for Science (grant IFS B/3025-2 to A Meikle); the International Atomic Energy Agency (URU/5/023 to D Cavestany) and the National Research Foundation of Hungary (OTKA-T/034 435 to M Kulcsar and H Febel).

\section{References}

Beam SW \& Butler WR 1997 Energy balance and ovarian follicle development prior to the first ovulation postpartum in dairy cows receiving three concentrations of dietary fat. Biology of Reproduction 56 133-142.

Beam SW \& Butler WR 1998 Energy balance, metabolic hormones, and early postpartum follicular development in dairy cows fed prilled lipid. Journal of Dairy Science 81 121-131.

Beam SW \& Butler WR 1999 Effects of energy balance on follicular development and first ovulation in postpartum dairy cow. Journal of Reproduction and Fertility Supplement 54 411-424.

Bertics SJ, Grummer RR, Cadorniga-Valino C \& Stoddard EE 1992 Effect of prepartum dry matter intake on liver triglyceride concentration and early lactation. Journal of Dairy Science $\mathbf{7 5}$ 1914-1922.

Block SS, Butler WR, Ehrhardt RA, Bell AW, Van Amburg ME \& Boisclair YR 2001 Decreased concentration of plasma leptin in periparturient dairy cows is caused by negative energy balance. Journal of Endocrinology 171 341-350.

Blum JW, Kunz P, Leunenberger H, Gautschi K \& Keller M 1983 Thyroid hormones, blood plasma metabolites and haematological parameters in relationship to milk yield in dairy cows. Animal Production 36 93-101.

Bocquier F, Bonnet M, Faulconnier Y, Guerre-Millo M, Martin P \& Chilliard Y 1998 Effects of photoperiod and feeding level on perirenal adipose tissue metabolic activity and leptin synthesis in the ovariectomized ewe. Reproduction, Nutrition, Development 38 489-498.

Butler WR 2000 Nutritional interactions with reproductive performance in dairy cattle. Animal Reproduction Science $60449-457$.

Butler WR \& Smith RD 1989 Interrelationship between energy balance and postpartum reproductive function in dairy cattle. Journal of Dairy Science 72 767-783.

Butler WR, Everett RW \& Coppok CE 1981 The relationships between energy balance, milk production and ovulation in postpartum Holstein cows. Journal of Animal Science 53 742-748.

Capuco AV, Wood DL, Elsasser TH, Kahl S, Erdmann RA, Van Tassell CP, Lefcourt A \& Piperova LS 2001 Effect of somatotropin on thyroid hormones and cytokines in lactacting dairy cows during ad libitum and restricted feed intake. Journal of Dairy Science 84 2430-2439.
Chilliard Y 1999 Metabolic adaptations and nutrient partitioning in the lactating animal. In Biology of Lactation, pp 503-552. Eds J Martinet, LM Houdebine \& HH Head. Paris: Inserm/INRA.

Chilliard Y, Bocquier F \& Doreau M 1998 Digestive and metabolic adaptations of ruminants to undernutrition and consequences on reproduction. Reproduction, Nutrition, Development 38 131-152.

Chilliard Y, Bonnet M, Delavaud C, Faulconnier Y, Leroux C, Djiane J \& Bocquier F 2001 Leptin in ruminants. Gene expression in adipose tissue and mammary gland, and regulation of plasma concentration. Domestic Animal Endocrinology 21 271-295.

Cissé M, Chilliard Y, Coxam V, Davicco MJ \& Remond B 1991 Slow release somatotropin in dairy heifers and cows fed two concentrations of energy concentrate. 2. Plasma hormones and metabolites. Journal of Dairy Science 74 1382-1394.

Clarke IJ \& Henry BA 1999 Leptin and reproduction. Reviews of Reproduction 4 48-55.

Delavaud C, Bocquier F, Chilliard Y, Keisler DH, Gertler A \& Kann G 2000 Plasma leptin determination in ruminants: effect of nutritional status and body fatness on plasma leptin concentrations assessed by a specific RIA in sheep. Journal of Endocrinology 165 $519-526$.

Delavaud C, Ferlay A, Faulconnier Y, Bocquier F, Kann G \& Chilliard Y 2002 Plasma leptin concentration in adult cattle: effects of breed, adiposity, feeding level and meal intake. Journal of Animal Science $\mathbf{8 0} 1317-1328$.

Edmonson AJ, Lean LJ, Weaver LD, Farver T \& Webster G 1989 A body condition scoring chart for Holstein dairy cows. Journal of Dairy Science 72 68-78.

Grant RJ \& Albright JL 2001 Effect of animal grouping on feeding behavior and intake of dairy cattle. Joint ADSA-ASAS Annual Meeting. Journal of Dairy Science 84 (Electronic Suppl) E156-E163.

Haydock KP \& Shaw NH 1975 The comparative yield method for estimating dry matter yield of pasture. Australian Journal of Experimental Agriculture and Animal Husbandry 15 663-670.

Heyden JM, Williams JE \& Collier JJ 1993 Plasma growth hormone, insulin-like growth factor, insulin, and thyroid hormone association with body protein and fat accretion in steers undergoing compensatory gain after dietary energy restriction. Journal of Animal Science 71 3327-3338.

Holtenius K, Agenas S, Delavaud C \& Chilliard Y 2003 Effects of feeding intensity during the dry period. 2. Metabolic and hormonal responses. Journal of Dairy Science $\mathbf{8 6} 883-891$.

Huszenicza Gy, Molnár L, Solti L \& Haraszti J 1987 Postpartal ovarian function in Holstein and crossbred cows on large scale farms in Hungary. Journal of Veterinary Medicine A 34 249-263.

Huszenicza Gy, Haraszti J, Molnár L, Solti L, Fekete S, Ekés K \& Yaro AC 1988 Some metabolic characteristics of dairy cows with different post partum ovarian function. Journal of Veterinary Medicine A 35 506-515.

Huszenicza Gy, Kulcsar M, Nikolic JA, Schmidt J, Korodi P, Katai L, Dieleman S, Ribiczei-Szabo P \& Rudas P 2001 Plasma leptin concentration and its interrelation with some blood metabolites, metabolic hormones and the resumption of cyclic ovarian function in postpartum dairy cows supplemented with Monensin or inert fat in feed. In Fertility in the High-Producing Dairy Cow, pp 405-409. Ed. MG Diskin. Edinburgh: British Society of Animal Science.

Huszenicza Gy, Kulcsar M \& Rudas P 2002 Clinical endocrinology of thyroid gland function in ruminants. Veterinarni Medicina $\mathbf{4 7}$ 199-210.

Ingvartsen KL \& Andersen JB 2000 Integration of metabolism and intake regulation: a review focusing on periparturient animals. Journal of Dairy Science 83 1573-1597.

Kadokawa H, Blache D, Yamada Y \& Martin GB 2000 Relationships between changes in plasma concentrations of leptin before and after parturition and the timing of first post-partum ovulation in high-producing Holstein dairy cows. Reproduction, Fertility, and Development 12 405-411. 
Kolver ES \& Muller LD 1998 Performance and nutrient intake of high producing Holstein cows consuming pasture or a total mixed ration. Journal of Dairy Science 81 1403-1411.

Kulcsar M, Danko G, Reiczigel J, Delavaud C, Chilliard Y, Magyar K \& Huszenicza Gy 2004 Pregnancy stage and number of foetuses may influence maternal plasma leptin in ewes. Acta Veterinaria Hungarica (In Press).

Liefers SC, Veerkamp RF, te Pas MFW, Delavaud C, Chilliard Y \& van der Lende T 2003 Leptin concentrations in relation to energy balance, milk yield, intake, live weight, and oestrus in dairy cows. Journal of Dairy Science 86 799-807.

Lucy MC 2001 Reproductive loss in high-producing dairy cattle: where will it end? Journal of Dairy Science 84 1277-1293.

Nikolic JA, Nedic O, Samanch H, Aleksic S, Miscevic B \& Kulcsar M 2001 Peripheral circulating insulin-like growth factor-I and II in cattle. Acta Veterinaria Hungarica 49 53-63.

Pethes G, Bokori J, Rudas P, Frenyo VL \& Fekete S 1985 Thyroxine, triiodothyronine, reverse-triiodothyronine, and other physiological characteristics of periparturient cows fed restricted energy. Journal of Dairy Science $\mathbf{6 8} 1148-1154$.

Reist $M$, Erdin $D$, von Euw $D$, Tschuemperlin $K$, Leuenberger $H$, Delavaud C, Chilliard Y, Hammon HM, Kuenzi N \& Blum JW 2003 Concentrate feeding strategy in lactating dairy cows: metabolic and endocrine changes with emphasis on leptin. Journal of Dairy Science 86 1690-1706.

Rémond B, Cisse M, Ollier A \& Chilliard Y 1991 Slow release somatotropin in dairy heifers and cows fed two levels of energy concentrate. Journal of Dairy Science 74 1370-1381.

Roberts AJ, Nugent RA, Klindt J \& Jenkins TG 1997 Circulating insulin-like growth factor 1 , insulin-like growth factor binding proteins, growth hormone, and resumption of oestrus in postpartum cows subjected to dietary energy restriction. Journal of Animal Science 75 1909-1917.

Spicer LJ 2001 Leptin: a possible metabolic signal affecting reproduction. Domestic Animal Endocrinology 21 251-270.

Spicer LJ \& Stewart RE 1996 Interactions among basic fibroblast growth factor, epidermal growth factor, insulin, and insulin-like growth factor-I (IGF-I) on cell numbers and steroidogenesis of bovine thecal cells: role of IGF-I receptors. Biology of Reproduction 54 255-263.

Spicer LJ, Tucker WB \& Adams GD 1990 Insulin-like growth factors in dairy cows: relationship among energy balance, body condition, ovarian activity and estrous behaviour. Journal of Dairy Science $\mathbf{7 3}$ 929-937.

Spicer LJ, Alpizar E \& Echternkamp SE 1993 Effects of insulin, insulin-like growth factor I, and gonadotropins on bovine granulosa cell proliferation, progesterone production, estradiol production, and (or) insulin-like growth factor I production in vitro. Journal of Animal Science 71 1232-1241.

Tamminga S, Luteijn PA \& Meijer RGM 1997 Changes in composition and energy content of liveweight loss in dairy cows with time after parturition. Livestock Production Science 52 31-39.

Taylor VJ, Beever DE, Bryant MJ \& Wathes DC 2003 Metabolic profiles and progesterone cycles in first lactation dairy cows. Theriogenology 59 1661-1677.

Verité R \& Chilliard Y 1992 Effect of age of dairy cows on body composition changes throughout the lactation cycle as measured with deuteriated water. Annales de Zootechnie $\mathbf{4 1} 118$.

Wathes DC, Taylor VJ, Cheng Z \& Mann GE 2003 Follicle growth, corpus luteum function and their effects on embryo development in postpartum dairy cows. Reproduction Supplement $\mathbf{6 1}$ $1-19$.

Whitaker DA, Goodger WJ, Garcia M, Perera BMAO \& Wittwer F 1999 Use of metabolic profiles in dairy cattle in tropical and subtropical countries on smallholder dairy farms. Preventative Veterinary Medicine 38 119-131.

Received 7 November 2003

First decision 21 January 2004

Revised manuscript received 4 March 2004

Accepted 25 March 2004 